\title{
Oceanobacillus oncorhynchi sp. nov., a halotolerant obligate alkaliphile isolated from the skin of a rainbow trout (Oncorhynchus mykiss), and emended description of the genus Oceanobacillus
}

Correspondence

Isao Yumoto

i.yumoto@aist.go.jp

\author{
Isao Yumoto, ${ }^{1,2}$ Kikue Hirota, ${ }^{1}$ Yoshinobu Nodasaka ${ }^{3}$ and Kenji Nakajima ${ }^{1}$ \\ ${ }^{1}$ Research Institute of Genome-based Biofactory, National Institute of Advanced Industrial \\ Science and Technology (AIST), Tsukisamu-Higashi, Toyohira-ku, Sapporo 062-8517, Japan \\ ${ }^{2}$ Graduate School of Agriculture, Hokkaido University, Kita-ku, Sapporo 060-8589, Japan \\ ${ }^{3}$ Laboratory of Electron Microscopy, Graduate School of Dentistry, Hokkaido University, Kita-ku, \\ Sapporo 060-8586, Japan
}

\begin{abstract}
A halotolerant, obligately alkaliphilic bacterium, $\mathrm{R}-2^{\top}$, was isolated from the skin of a rainbow trout (Oncorhynchus mykiss), a freshwater fish. The strain is Gram-positive, ferments several carbohydrates, is rod-shaped and motile by peritrichous flagella and produces ellipsoidal spores. The isolate grows at $\mathrm{pH} 9-10$ but not at $\mathrm{pH} 7-8$. This micro-organism grows in $0-22 \%(\mathrm{w} / \mathrm{v})$ $\mathrm{NaCl}$ at $\mathrm{pH} 10$. Its major cellular fatty acids are iso- $\mathrm{C}_{15: 0}$, anteiso- $\mathrm{C}_{15: 0}$ and anteiso- $\mathrm{C}_{17: 0}$, the major isoprenoid quinone is MK-7 and the DNA G $+C$ content is $38.5 \mathrm{~mol} \%$. Phylogenetic analysis based on $16 \mathrm{~S}$ rRNA gene sequences indicates that strain $\mathrm{R}^{-}{ }^{\top}{ }^{\top}$ is a member of the genus Oceanobacillus. DNA-DNA hybridization reveals low relatedness between the isolate and Oceanobacillus iheyensis $(21.0 \%)$. On the basis of phenotypic characteristics, phylogenetic data and DNA-DNA relatedness data, the isolate should be designated as a novel species, for which the name Oceanobacillus oncorhynchi sp. nov. is proposed. The type strain is $\mathrm{R}-2^{\top}$ ( $=\mathrm{JCM}$ $12661^{\top}=$ NCIMB $14022^{\top}$ ).
\end{abstract}

Alkaliphilic micro-organisms are very important in basic research as well as in industrial applications. These organisms have been studied for the industrial application of their enzymes, to understand the physiology of alkali adaptation and to elucidate their taxonomy and ecology (Horikoshi, 1991; Duckworth et al., 1996; Takami et al., 1997; Krulwich \& Guffanti, 1989; Krulwich et al., 2001; Yumoto, 2002, 2003; Thongaram et al., 2003). Alkaliphiles are widely distributed in soils and related environments, in marine settings and in freshwater. Many of the alkaliphiles encountered belong to the genus Bacillus, which clusters into several phylogenetic groups. Recently, several Bacillus species have been reclassified into several novel genera, or novel genera of strains related to the genus Bacillus have been discovered, such as Gracilibacillus (Wainø et al., 1999), Halobacillus (Spring et al., 1996), Virgibacillus (Heyndrickx et al., 1998), Salibacillus (Wainø et al., 1999), Geobacillus (Nazina et al., 2001), Anoxybacillus (Pikuta et al., 2000) and

Published online ahead of print on 17 February 2005 as DOI 10.1099/ ijs.0.63483-0.

The GenBank/EMBL/DDBJ accession number for the $16 \mathrm{~S}$ rRNA gene sequence of strain $R-2^{\top}$ is $A B 188089$.
Oceanobacillus (Lu et al., 2001). Of these, the genera Anoxybacillus and Oceanobacillus contain alkaliphilic strains. As reports on alkaliphiles from freshwater and related environments are scant (Horikoshi, 1991; Nielsen et al., 1995), we initiated a study to investigate such microorganisms. A halotolerant obligate alkaliphile not belonging to the genus Bacillus was isolated from a freshwater fish. Phenotypic and chemotaxonomic characterization, phylogenetic analysis based on the 16S rRNA gene sequence and DNA-DNA hybridization with close neighbours showed that the isolate merited classification as a novel Oceanobacillus species.

The sample fish used, a rainbow trout (approx. $40 \mathrm{~cm}$ long), was obtained from a freshwater fish pond in Sapporo (Hokkaido, Japan). A viscous liquid (approx. $1 \mathrm{ml}$ ) obtained from the fish skin was inoculated into $250 \mathrm{ml}$ PYA broth ( $\mathrm{pH} \mathrm{10)}$ in a $500 \mathrm{ml}$ flask. The medium comprised the following: $8 \mathrm{~g}$ peptone (Kyokuto), $3 \mathrm{~g}$ yeast extract (Merck), $1 \mathrm{~g} \mathrm{~K}_{2} \mathrm{HPO}_{4}, 3.5 \mathrm{mg}$ EDTA, $3 \mathrm{mg}$ $\mathrm{ZnSO}_{4} .7 \mathrm{H}_{2} \mathrm{O}, 10 \mathrm{mg} \mathrm{FeSO}_{4} .7 \mathrm{H}_{2} \mathrm{O}, 2 \mathrm{mg} \mathrm{MnSO}_{4} \cdot 5 \mathrm{H}_{2} \mathrm{O}$, $1 \mathrm{mg} \mathrm{CuSO}_{4} .5 \mathrm{H}_{2} \mathrm{O}, 2 \mathrm{mg} \mathrm{Co}\left(\mathrm{NO}_{3}\right)_{2} \cdot 6 \mathrm{H}_{2} \mathrm{O}$ and $1 \mathrm{mg}$ $\mathrm{H}_{3} \mathrm{BO}_{3}$ in $11 \mathrm{NaHCO} / \mathrm{Na}_{2} \mathrm{CO}_{3}$ buffer $(100 \mathrm{mM}$ in 
deionized water; $\mathrm{pH} 10)$ and was incubated with reciprocal shaking (140 r.p.m.) at $27^{\circ} \mathrm{C}$ for $30 \mathrm{~h}$. A loopful of culture broth was spread on a PYA agar plate. The isolate obtained from the plate was reisolated five times and maintained on a PYA agar slant. Cells for chemotaxonomic analysis were harvested in the late exponential phase of growth during cultivation with reciprocal shaking (140 r.p.m.) at $27^{\circ} \mathrm{C}$. In addition to the isolate, Oceanobacillus iheyensis JCM $11309^{\mathrm{T}}$, Virgibacillus pantothenticus IAM $11061^{\mathrm{T}}$ and Virgibacillus picturae DSM $14867^{\mathrm{T}}$ were used as reference strains for DNA-DNA hybridization. These micro-organisms were cultivated using PYA broth containing $100 \mathrm{mM} \mathrm{NaHCO} /$ $\mathrm{Na}_{2} \mathrm{CO}_{3}$ buffer ( $\mathrm{pH} 10$ ) and the same broth medium containing $100 \mathrm{mM} \mathrm{NaH}{ }_{2} \mathrm{PO}_{4} / \mathrm{Na}_{2} \mathrm{HPO}_{4}(\mathrm{pH}$ 7).

For the phenotypic characterization, PYA medium was used as the basal medium. All of the experiments were performed under aerobic conditions (except the tests on carbohydrate metabolism under anaerobic conditions). The culture was incubated at $27^{\circ} \mathrm{C}$ for 2 weeks and the experiment was performed three times. Acid production from carbohydrates was determined by the method of Hugh \& Leifson (1953) using thymol blue $(0.008 \%$, w/v) instead of bromothymol blue at $\mathrm{pH} 10$. Growth experiments at pH 7-10 were performed using PYA broth containing $100 \mathrm{mM} \mathrm{NaH} \mathrm{PO}_{4} / \mathrm{Na}_{2} \mathrm{HPO}_{4}$ buffer (pH 7-8) or $100 \mathrm{mM}$ $\mathrm{NaHCO}_{3} / \mathrm{Na}_{2} \mathrm{CO}_{3}$ buffer (pH 9-10). Other physiological and biochemical characteristics were examined according to the methods of Yumoto et al. (1998) and as described by Barrow \& Feltham (1993). For observation of negatively stained cells by transmission electron microscopy ( $\mathrm{H}-800$ apparatus; Hitachi), cells were grown on a PYA agar slant. The transmission electron microscopy preparations and observations were performed as described previously (Yumoto et al., 2001). The morphological, physiological and biochemical characteristics of the isolate are given in the species description. The isolate was revealed to be Grampositive and to produce ellipsoidal spores positioned subterminally within a swollen sporangium. Electron microscopy showed that the cells were peritrichously flagellated rods $(0 \cdot 4-0.6 \times 1 \cdot 1-1 \cdot 4 \mu \mathrm{m})$.

Analyses of whole-cell fatty acids and isoprenoid quinones were performed as described previously (Yumoto et al., 2001). GLC (GC-353 apparatus; GL Sciences) analysis of the fatty acids of strain $\mathrm{R}-2^{\mathrm{T}}$ revealed that the measurable components were iso- $\mathrm{C}_{14: 0}(1 \cdot 1 \%)$, iso- $\mathrm{C}_{15: 0}(22 \cdot 7 \%)$, anteiso- $\mathrm{C}_{15: 0}(49 \cdot 3 \%)$, iso- $\mathrm{C}_{16: 0}(3 \cdot 2 \%), \mathrm{C}_{16: 0}(2 \cdot 1 \%)$, iso- $\mathrm{C}_{17: 0}(4 \cdot 3 \%)$ and anteiso- $\mathrm{C}_{17: 0}(18 \cdot 0 \%)$. The major isoprenoid quinone was MK-7.

Bacterial DNA was prepared according to the method of Marmur (1961). The DNA G +C content was determined by the method of Tamaoka \& Komagata (1984): the value for strain $\mathrm{R}-2^{\mathrm{T}}$ was $38.5 \mathrm{~mol} \%$, which is higher than that of O. iheyensis JCM $11309^{\mathrm{T}}(35 \cdot 8 \mathrm{~mol} \%)$ (Lu et al., 2001).

The 16S rRNA gene sequence of strain R-2 ${ }^{\mathrm{T}}$ was analysed to determine its phylogenetic position. The $16 \mathrm{~S}$ rRNA gene was amplified using the PCR method, with primers 9F (5'GAGTTTGATCCTGGCTCAG) and 1541R (5'-AAGGAGGTGATCCAGCC). The PCR product (approximately $1.5 \mathrm{~kb}$ ) was sequenced directly by the dideoxynucleotide chain-termination method using a DNA sequencer (ABI PRISM 3100) with BigDye Termination RR mix version 3.1 (Applied Biosystems) according to the manufacturer's instructions. Primers 9F, 339F, 785F, 1224F and 802R were used in the gene sequencing reaction. Multiple alignments of the sequence were performed and the nucleotide substitution rate ( $K_{\text {nuc }}$ value) was calculated. A phylogenetic tree was constructed by the neighbour-joining method (Kimura, 1980; Saitou \& Nei, 1987) using the CLUSTAL W program (Thompson et al., 1994). Sequence similarity was calculated using the GENETYX computer program (Software Development). The sequence of 1451 bases of the 16S rRNA gene of strain $\mathrm{R}-2^{\mathrm{T}}$ was compared with those of previously reported strains. A phylogenetic tree constructed using these data (Fig. 1) showed that strain R-2 ${ }^{\mathrm{T}}$ formed a monophyletic group with $O$. iheyensis. Strain $\mathrm{R}-2^{\mathrm{T}}$ showed the highest similarity with O. iheyensis JCM $11309^{\mathrm{T}}(96 \cdot 7 \%)$. The similarities between strain $\mathrm{R}-2^{\mathrm{T}}$ and other phylogenetic neighbours were as follows: $94 \cdot 3 \%$ (Virgibacillus halodenitrificans ATCC $49067^{\mathrm{T}}$ ), $93 \cdot 8 \%$ (V. pantothenticus IAM $11061^{\mathrm{T}}$ ), $93 \cdot 3 \%$ (Bacillus lentus NCIMB $8773^{\mathrm{T}}$ ) and $93.3 \%$ (Bacillus niacini NBRC $15566^{\mathrm{T}}$ ). Other taxa exhibited even lower similarities to strain $\mathrm{R}-2^{\mathrm{T}}$.

The level of DNA-DNA relatedness was determined fluorometrically by using the method of Ezaki et al. (1989) with photobiotin-labelled DNA probes, prepared using Photoprobe biotin (SP1000; Vector Laboratories) and black microplates (F16 Black Maxisorp; Nage Nunc International). The results of sequence similarity and phylogenetic analyses based on 16S rRNA gene sequences

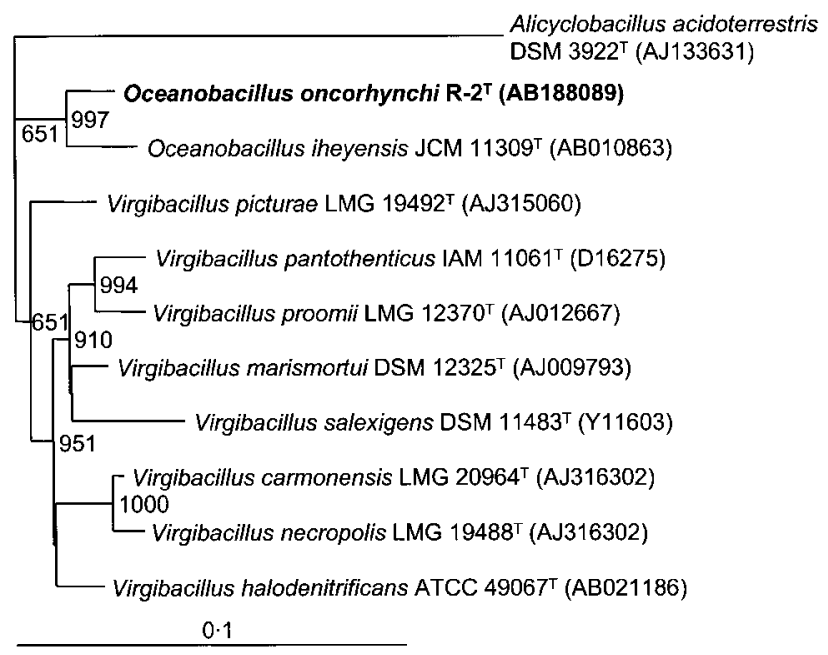

Fig. 1. Phylogenetic tree derived from 16S rRNA gene sequences of $\mathrm{O}$. oncorhynchi $\mathrm{R}-2^{\top}$ and other related organisms using the neighbour-joining method. Bootstrap values from 1000 replications are shown at branching points. Bar, $0 \cdot 1 K_{\text {nuc }}$. 
show that strain $\mathrm{R}-2^{\mathrm{T}}$ is closely related to O. iheyensis JCM $11309^{\mathrm{T}}$. Therefore, DNA-DNA hybridization between strain R-2 $2^{\mathrm{T}}$ and $O$. iheyensis JCM $11309^{\mathrm{T}}$ and the phylogenetic neighbours $V$. pantothenticus IAM $11061^{\mathrm{T}}$ and $V$. picturae DSM $14867^{\mathrm{T}}$ was performed. The DNA-DNA hybridization data indicated that the isolate is distinct from $O$. iheyensis $\mathrm{JCM} 11309^{\mathrm{T}}(21 \cdot 0 \%$ relatedness $), V$. pantothenticus IAM $11061^{\mathrm{T}}(12 \cdot 1 \%$ relatedness $)$ and $V$. picturae DSM $14867^{\mathrm{T}}(5 \cdot 4 \%$ relatedness $)$.

GLC analysis of the fatty acids of O. iheyensis JCM $11309^{\mathrm{T}}$ revealed that the measurable components were iso$\mathrm{C}_{14: 0}(13 \cdot 0 \%)$, iso- $\mathrm{C}_{15: 0}(34 \cdot 3 \%)$, anteiso- $\mathrm{C}_{15: 0}(38 \cdot 7 \%)$, iso- $\mathrm{C}_{16: 0}(7 \cdot 8 \%), \mathrm{C}_{16: 0}(1 \cdot 1 \%)$, iso- $\mathrm{C}_{17: 0}(1 \cdot 1 \%)$ and anteiso- $\mathrm{C}_{17: 0}(4 \cdot 1 \%)$. Obvious differences in iso- $\mathrm{C}_{14: 0}$ and anteiso- $\mathrm{C}_{17: 0}$ content between strain $\mathrm{R}-2^{\mathrm{T}}$ and $O$. iheyensis JCM $11309^{\mathrm{T}}$ were observed. Strain R-2 $2^{\mathrm{T}}$ can be also differentiated from $O$. iheyensis JCM $11309^{\mathrm{T}}$ on the basis of several phenotypic and chemotaxonomic characteristics (Table 1).

The source of the first isolate belonging to the genus Oceanobacillus was deep-sea sediment (Lu et al., 2001). Although strain $\mathrm{R}-2^{\mathrm{T}}$ grows better with $\mathrm{NaCl}$ and tolerates very high $\mathrm{NaCl}$ concentrations, it can grow well in culture broth without $\mathrm{NaCl}$. This means that the presence of $\mathrm{NaCl}$ in the medium is not essential for growth of strain R-2 ${ }^{\mathrm{T}}$. In summary, we have isolated a novel Oceanobacillus species from a fish living in fresh water. On the basis of the characteristics of the first isolate identified as belonging to the genus Oceanobacillus, O. iheyensis JCM $11309^{\mathrm{T}}$, this genus has been considered to contain only obligately aerobic, facultative alkaliphiles. However, a facultatively anaerobic and obligately alkaliphilic strain was isolated in the present study, which means that the genus Oceanobacillus contains species exhibiting a variety of phenotypic characteristics.

On the basis of the above results, the isolate was designated as a novel species, for which the name Oceanobacillus oncorhynchi sp. nov. is proposed.

\section{Emended description of genus Oceanobacillus Lu et al. 2002}

Oceanobacillus (O.ce.a.no.ba.cil'lus. L. n. oceanus the ocean; L. dim. n. bacillus a small rod; N.L. masc. n. Oceanobacillus the ocean bacillus/rod).

Gram-positive, spore-forming rods, motile by means of peritrichous flagella. Ellipsoidal spores are subterminal or terminal within swollen sporangia. Colonies are circular and white. Obligately aerobic or facultatively anaerobic, obligately or facultatively alkaliphilic and grows at $0-22 \%$ $(\mathrm{w} / \mathrm{v}) \mathrm{NaCl}$. Catalase and oxidase reactions are positive. Growth occurs at temperatures of $15-42{ }^{\circ} \mathrm{C}$. The major cellular fatty acids are iso- $\mathrm{C}_{15: 0}$ and anteiso- $\mathrm{C}_{15: 0}$. The major isoprenoid quinone is MK-7. The DNA G +C content is $35 \cdot 8-38 \cdot 5 \mathrm{~mol} \%$. The type species is Oceanobacillus iheyensis.

\section{Description of Oceanobacillus oncorhynchi sp. nov.}

Oceanobacillus oncorhynchi (on.co.rhyn'chi. N.L. gen. n. oncorhynchi of Oncorhynchus, named after the rainbow trout, Oncorhynchus mykiss, from which the type strain was isolated).

Cells are Gram-positive, peritrichously flagellated straight rods $(0 \cdot 4-0.6 \times 1 \cdot 1-1 \cdot 4 \mu \mathrm{m})$ and produce ellipsoidal spores subterminally positioned within swollen sporangia. Colonies are circular and white. Ferments several carbohydrates and is obligately alkaliphilic. Grows at pH 9-10 but not at $\mathrm{pH} 7-8$. Catalase and oxidase reactions are positive. Growth occurs at $15-40{ }^{\circ} \mathrm{C}$, with the optimum at $30-36^{\circ} \mathrm{C}$. Negative for indole production, ONPG hydrolysis and deamination of phenylalanine. Growth occurs at $0-22 \%$

Table 1. Differentiating characteristics of $O$. oncorhynchi and $O$. iheyensis

Data for O. iheyensis are from Lu et al. (2001).

\begin{tabular}{|c|c|c|}
\hline Characteristic & O. oncorhynchi $\mathrm{R}-2^{\mathrm{T}}$ & O. iheyensis $\mathrm{JCM} 11309^{\mathrm{T}}$ \\
\hline Cell size $(\mu \mathrm{m})$ & $0 \cdot 4-0 \cdot 6 \times 1 \cdot 1-1 \cdot 4$ & $0 \cdot 6-0 \cdot 8 \times 2 \cdot 5-3 \cdot 5$ \\
\hline Growth $\mathrm{pH}$ range & $9 \cdot 0-10 \cdot 0$ & $6 \cdot 5-10 \cdot 0$ \\
\hline Anaerobic growth & + & - \\
\hline \multicolumn{3}{|l|}{ Hydrolysis of: } \\
\hline Gelatin & - & + \\
\hline Casein & - & + \\
\hline DNA & - & + \\
\hline Tween 60 & - & + \\
\hline Reduction of $\mathrm{NO}_{3}^{-}$to $\mathrm{NO}_{2}^{-}$ & + & - \\
\hline Major cellular fatty acids & $\begin{array}{l}\text { iso- } \mathrm{C}_{15: 0} \text {, anteiso- } \mathrm{C}_{15: 0} \\
\text { anteiso- } \mathrm{C}_{17: 0}\end{array}$ & $\begin{array}{l}\text { iso- } \mathrm{C}_{15: 0} \text {, anteiso- } \mathrm{C}_{15: 0} \text {, } \\
\text { iso- } \mathrm{C}_{14: 0}\end{array}$ \\
\hline DNA G + C content $(\mathrm{mol} \%)$ & $38 \cdot 5$ & $35 \cdot 8$ \\
\hline
\end{tabular}


(w/v) $\mathrm{NaCl}$, with the optimum at $7 \%(\mathrm{w} / \mathrm{v})$. Nitrate is reduced to nitrite. Acid is produced from D-glucose, Dfructose, maltose, D-mannose, melibiose, sucrose, raffinose, D-galactose and trehalose. No acid is produced from D-arabinose, D-xylose, myo-inositol, sorbitol or lactose. Hydrolyses Tween 40. Negative for hydrolysis of casein, gelatin, starch, DNA, lipid (tributyrin) and Tweens 20, 60 and 80 . The fatty acid components are iso- $\mathrm{C}_{14: 0}(1 \cdot 1 \%)$, iso- $\mathrm{C}_{15: 0}(22 \cdot 7 \%)$, anteiso- $\mathrm{C}_{15: 0}(49 \cdot 3 \%)$, iso- $\mathrm{C}_{16: 0}$ $(3 \cdot 2 \%), \mathrm{C}_{16: 0}(2 \cdot 1 \%)$, iso- $\mathrm{C}_{17: 0}(4 \cdot 3 \%)$ and anteiso$\mathrm{C}_{17: 0}(18 \cdot 0 \%)$. The major isoprenoid quinone is $\mathrm{MK}-7$. The DNA G $+\mathrm{C}$ content of the type strain is $38 \cdot 5 \mathrm{~mol} \%$.

The type strain, strain R-2 $2^{\mathrm{T}}\left(=\mathrm{JCM} \quad 12661^{\mathrm{T}}=\mathrm{NCIMB}\right.$ $14022^{\mathrm{T}}$ ), was isolated from the skin of a rainbow trout (Oncorhynchus mykiss) living in freshwater.

\section{References}

Barrow, G. I. \& Feltham, R. K. A. (1993). Cowan and Steel's Manual for the Identification of Medical Bacteria, 3rd edn. Cambridge: Cambridge University Press.

Duckworth, A. W., Grant, W. D., Jones, B. E. \& Steenbergen, R. (1996). Phylogenetic diversity of soda lake alkaliphiles. FEMS Microbiol Lett 19, 181-191.

Ezaki, T., Hashimoto, Y. \& Yabuuchi, E. (1989). Fluorometric deoxyribonucleic acid-deoxyribonucleic acid hybridization as an alternative to membrane filter hybridization in which radioisotopes are used to determine genetic relatedness among bacterial strains. Int J Syst Bacteriol 39, 224-229.

Heyndrickx, M., Lebbe, L., Kersters, K., De Vos, P., Forsyth, G. \& Logan, N. A. (1998). Virgibacillus: a new genus to accommodate Bacillus pantothenticus (Proom and Knight 1950). Emended description of Virgibacillus pantothenticus. Int J Syst Bacteriol 48, 99-106.

Horikoshi, K. (1991). Microorganisms in Alkaline Environments. Weinheim: VCH.

Hugh, R. \& Leifson, E. (1953). The taxonomic significance of fermentative versus oxidative metabolism of carbohydrates by various gram negative bacteria. J Bacteriol 66, 24-26.

Kimura, M. (1980). A simple method for estimating evolutionary rates of base substitutions through comparative studies of nucleotide sequences. J Mol Evol 16, 111-120.

Krulwich, T. A. \& Guffanti, A. A. (1989). Alkalophilic bacteria. Annu Rev Microbiol 43, 435-463.

Krulwich, T. A., Ito, M. \& Guffanti, A. A. (2001). The $\mathrm{Na}^{+}$-dependence of alkaliphily in Bacillus. Biochim Biophys Acta 1505, 158-168.

Lu, J., Nogi, Y. \& Takami, H. (2001). Oceanobacillus iheyensis gen. nov., sp. nov., a deep-sea extremely halotolerant and alkaliphilic species isolated from a depth of $1050 \mathrm{~m}$ on the Iheya Ridge. FEMS Microbiol Lett 205, 291-297.

Marmur, J. (1961). A procedure for the isolation of deoxyribonucleic acid from micro-organisms. J Mol Biol 3, 208-218.

Nazina, T. N., Tourova, T. P., Poltaraus, A. B. \& 8 other authors (2001). Taxonomic study of aerobic thermophilic bacilli: description of Geobacillus subterraneus gen. nov., sp. nov. and Geobacillus uzenensis sp. nov. from petroleum reservoirs and transfer of Bacillus stearothermophilus, Bacillus thermocatenulatus, Bacillus thermoleovorans, Bacillus kaustophilus, Bacillus thermoglucosidasius and Bacillus thermodenitrificans to Geobacillus as the new combinations $G$. stearothermophilus, G. thermocatenulatus, G. thermoleovorans, $G$. kaustophilus, G. thermoglucosidasius and G. thermodenitrificans. Int J Syst Evol Microbiol 51, 433-446.

Nielsen, P., Fritze, D. \& Priest, F. G. (1995). Phenetic diversity of alkaliphilic Bacillus strains: proposal for nine new species. Microbiology 141, 1745-1761.

Pikuta, E., Lysenko, A., Chuvilskaya, N., Mendrock, U., Hippe, H., Suzina, N., Nikitin, D., Osipov, G. \& Laurinavichius, K. (2000). Anoxybacillus pushchinensis gen. nov., sp. nov., a novel anaerobic alkaliphilic, moderately thermophilic bacterium from manure, and description of Anoxybacillus flavithermus comb. nov. Int J Syst Evol Microbiol 50, 2109-2117.

Saitou, N. \& Nei, M. (1987). The neighbor-joining method: a new method for reconstructing phylogenetic trees. Mol Biol Evol 4, 406-425.

Spring, S., Ludwig, W., Márquez, M. C., Ventose, A. \& Schleifer, K. H. (1996). Halobacillus gen. nov., with descriptions of Halobacillus litoralis sp. nov. and Halobacillus trueperi sp. nov., and transfer of Sporosarcina halophila to Halobacillus halophilus comb. nov. Int J Syst Bacteriol 46, 492-496.

Takami, H., Inoue, A., Fujii, F. \& Horikoshi, K. (1997). Microbial flora in the deepest sea mud of the Mariana Trench. FEMS Microbiol Lett 152, 279-285.

Tamaoka, J. \& Komagata, K. (1984). Determination of DNA base composition by reversed-phase high-performance liquid chromatography. FEMS Microbiol Lett 25, 125-128.

Thompson, J. D., Higgins, D. G. \& Gibson, T. J. (1994). CLUSTAL W: improving the sensitivity of progressive multiple sequence alignment through sequence weighting, position-specific gap penalties and weight matrix choice. Nucleic Acids Res 22, 4673-4680.

Thongaram, T., Kosono, S., Ohkuma, M., Hongoh, Y., Kitada, M., Yoshinaka, T., Trakulnaleamsai, S., Noparatnaraporn, N. \& Kudo, T. (2003). Gut of higher termites as a niche for alkaliphiles as shown by culture-based and culture-independent studies. Microbes Environ 18, 152-159.

Wainø, M., Tindall, B. J., Schumann, P. \& Ingvorsen, K. (1999). Gracilibacillus gen. nov., with description of Gracilibacillus halotolerans gen. nov., sp. nov.; transfer of Bacillus dipsosauri to Gracilibacillus dipsosauri comb. nov., and Bacillus salexigens to the genus Salibacillus gen. nov., as Salibacillus salexigens comb. nov. Int J Syst Bacteriol 49, 821-831.

Yumoto, I. (2002). Bioenergetics of alkaliphilic Bacillus spp. J Biosci Bioeng 93, 342-353.

Yumoto, I. (2003). Electron transport system in alkaliphilic Bacillus spp. Recent Res Devel Bacteriol 1, 131-149.

Yumoto, I., Yamazaki, K., Sawabe, T., Nakano, K., Kawasaki, K., Ezura, Y. \& Shinano, H. (1998). Bacillus horti sp. nov., a new Gramnegative alkaliphilic bacillus. Int J Syst Bacteriol 48, 565-571.

Yumoto, I., Yamazaki, K., Hishinuma, M., Nodasaka, Y., Suemori, A., Nakajima, K., Inoue, N. \& Kawasaki, K. (2001). Pseudomonas alcaliphila sp. nov., a novel facultatively psychrophilic alkaliphile isolated from seawater. Int J Syst Evol Microbiol 51, 349-355. 